\title{
The IMAGES ocean coring and scientific cooperation efforts
}

IMAGES has been initiated to respond to the challenge of understanding the mechanisms and consequences of climatic changes using oceanic sedimentary records. Climatic mechanisms must be studied at global scale using sophisticated models based on high quality data that represent the variability of surface and deep ocean physical and chemical characteristics during key periods of recent earth history. Individual research is no longer sufficient to resolve this problem, because the acquisition of the long sediment cores needed from high sedimentation rate areas is expensive, and the proper study of such cores demands the use of multiple tools and large numbers of measurements.

IMAGES has been established by IGBP-PAGES and SCOR to meet these demands. Its major goal is to foster coordination, at the international level, of scientific programs that address the scientific goals outlined in the IMAGES «Science and Implementation Plan». Operational support, based on specific scientific proposals, is sought from national or international scientific agencies.

The following countries and associations of institutions have pledged multi-year funding starting in 1996 or 1997:

USA (NSF MESH program), France (PNEDC program), Consortium of German Institutions (Bremen Univ., Kiel Univ. GEOMAR-Kiel, AWI-Bremerhaven), Consortium of Canadian Institutions (coord. by Univ. of New Brunswick), Consortium of Universities from China, Taiwan, Great Britain (NERC), Consortium New Zealand-Australia, Norway, Portugal and South Africa. Japan will join in 1998. Proposals are in progress in Denmark, Sweden, Spain, Russia, Holland and Tunisia.

The next Scientific Committee will meet in Stockholm, August 15-17, 1997, just prior to the conference which commemorates the 50th Anniversary of the Albatross Swedish Deep-Sea Expedition (1947-1948) : "Development of Paleoceanography as a New Field of Science".

\section{IMAGES working groups, workshops, international cruises and other activities}

Several working groups, accepted in general terms by the 1996 Scientific Committee, have been or will be launched within 1997:

\section{WG1 : North Atlantic Ultra high resolution study of the variability of surface and deep water hydrology in relation with local and global climate Chair: E. Jansen (Jansen@geol.vib.no)}

Objective: Selection of sites for giant coring, during the course of a proposed 1998 or 1999 Marion Dufresne cruise. An international proposal is in preparation for giant coring with Marion Dufresne in fjords and estuaries of the Nordic and Arctic seas, with inputs from Norway, Iceland, Russia, Canada and France. The focus will be decadal variability of the last several thousand years (the Holocene).

\section{WG2: Western Pacific Warm Pool and Kuroshio WEPAMA}

Chair: Kuo-Yen Wei (weiky@cc.ntu.edu.tw) Objective: Western Pacific warm pool, western boundary currents (Kuroshio, East Australian current), exchange between marginal seas and open ocean, sea level effects, correlation between Northern and Southern Hemispheres, comparisons between marine and continental records. Preparation of a giant coring cruise and ODP drillings along the western margins of the Pacific Ocean by the year 2000.

\section{Data Handling Working Group}

Chair: D. Anderson (dma@paleosun.ngdc.noaa.gov) IMAGES consider it imperative to have a small group of people acting as a permanent source of advice (by e-mail or direct contact). Problems are encountered in all data bank systems, and there is a rapidly developing knowledge of what to do and what not to do.

\section{- Future Working Groups in preparation}

\section{Monsoon variability (with SCOR)}

Chair: P. Wang (China)

Objective: A detailed analysis of the comparative variability of the Indian and East Asian Monsoons. Report and/or Conference in preparation for future cruises and ODPlegs. To be established in 1998 if approved by SCOR.

Western Margins of the Americas, Alaska
to Chile (in close relationship to PEP 1/V.
Margraff), with SCOR, PAGES or the Inter
American Agency
Project prepared by A. Mix (mix@oce.orst.edu)
and T. Pedersen (tfp@unixg.ubc.ca)
Project to be defined in time for submission to
the next Scicom, summer 1997, for the study of
the North-South climatic connexions with
comparison of the oceanic and continental
records.

It aims at a giant coring cruise on margins and estuaries of the Western America coasts in the years 2000-2001.

Southern Ocean, with SCAR, PAGES

Proposed chairs: R. Gersunde and D. Hodell

Project to be defined in time for submission to the next Scicom, summer 1997. Aims at giant coring cruises and ODP legs in the years 1999-2001.

\section{A specific action is considered with SCAR: ANTIME}

Chair: lan Goodwin (lan.Goodwin@utas.edu.au) ANTIME aims to core or drill high sedimentation rate areas around Antarctica for the study of decadal climatic variability during the Holocene.

\section{Working group on the revaluation of the CLIMAP 18kyrBP reference sea surface temperature map}

A workshop is planned by Allan Mix and Edovard Bard as a co-organizer.

This working group has been created after a specific demand from the climate modellers (PMIP, in particular), the $18 \mathrm{kyr} \mathrm{BP}$ reconstruction playing a crucial role for testing climate and ocean models for different climatic conditions. They need, as soon as possible, an improved data set (CD ROM, for example) with a re-evaluation of the most criticised aspects of the CLIMAP reconstruction: sea ice cover, low latitude temperature, separation of the productivity effects on the transfer function, comparison with $\mathrm{Uk}_{37}$ potential for salinity reconstruction, more precise temporal framework, with the precise definition of what is taken as the LGM (maximum ice extension, or maximum ice volume?), and relation to Heinrich events 1 and 2 which correspond to minimum temperatures in large areas of the northern hemisphere.

\section{Sediment imaging technical working group \\ Chair: F. Rack (rack@omg.unb.ca)}

The need for developing rapidly ultra high resolution studies on long sedimentary series and a very large number of cores will demand new approaches for data acquisition tools and relations with proxies. It will be necessary to quantify continuously the perturbations introduced by bioturbation and sampling; to develop secondary proxies for interpolating changes between the more quantitative proxies which need sampling of large volumes of sediments (isotopes, micropaleontological transfer functions, geochemical parameters...) The 1-dimensional continuous records obtained by tools such as the Geotek multiSensor Track represent significant progress, but are still not sufficient. Tools must now be 
developed for 2D and 3D imaging with at least millimetric resolution, and acting on a large array of physical characteristics (to multiply the number of proxies which may be independently estimated). Expensive X-Ray video digital systems, and much too primitive colour reflectance video imaging already exist.

\section{- Symposia}

Two large symposia have been organized:

\section{American Geophysical Union,}

San Francisco, USA, December 1996

"North Atlantic Variability and Global Climate

Change"

Convenors: F. Bassinot and D. Oppo

15 oral presentations and 53 posters, about 400 participants.

\section{European Union of Geosciences,}

Strasbourg, France, March 97

"Proxies in Paleoceanography and

Paleoclimatology"

Convenors: M. Sarnthein, E. Jansen, L. Labeyrie

50 oral presentations and 34 posters, about 300 participants.
The IMAGES community will participate in the 1998 London PAGES Open Science meeting, but its main rendez-vous, that year, and subsequently every 3 years, will be the:

International Conference on
Paleoceanography - ICP VI
Lisbon, Portugal, August 23 - 28, 1998
Convenor: F. Abrantes
(icp6fatima@mail.telepac.pt)
The major theme of the Conference is
"Reconstructing Ocean History-a Window
into the Future" with five major topics:
- Polar-tropical and interhemisphere
linkages
- Does the ocean cause or respond to
abrupt climatic changes?
- Biotic responses to major
paleoceanographic changes
- Past warm climates
- Innovations in monitoring ocean history

\section{- IMAGES cruises}

Three international giant coring cruises have already been organized on board the French R.V. Marion Dufresne, to demonstrate the feasibility of large scale international collaboration focused on specific paleooceanographic objectives (Fig. 1):

\section{IMAGES 1 (MD 100, May-July 95)}

Northern Atlantic and Norwegian Sea

Chief scientists: L. Labeyrie, E. Boyle, Y. Lancelot

The main objective was coring in high sedimentation rate areas ( 10 to $20 \mathrm{~cm} / \mathrm{kyr}$ ) in zones well adapted for the study of the rapid variability of the thermohaline circulation in relation to ice sheets dynamics and global climate. 22 countries and 70 scientists participated. Funding for the program came from agencies in France, Canada, Germany, the U.S. for the main participants, and Norway, U.K. and Spain as additional projects. The cruise fulfilled most of its objectives, with the collection of 43 long (to $53 \mathrm{~m}$ ), large diameter piston cores at 41 locations.

\section{IMAGES 2 (Nausicaa MD 105, Oct-Nov 96) Western and Eastern margins of South Africa}

\section{Chief scientist: P. Bertrand}

The main objectives were the history of the Indian and Atlantic Oceans connection and of

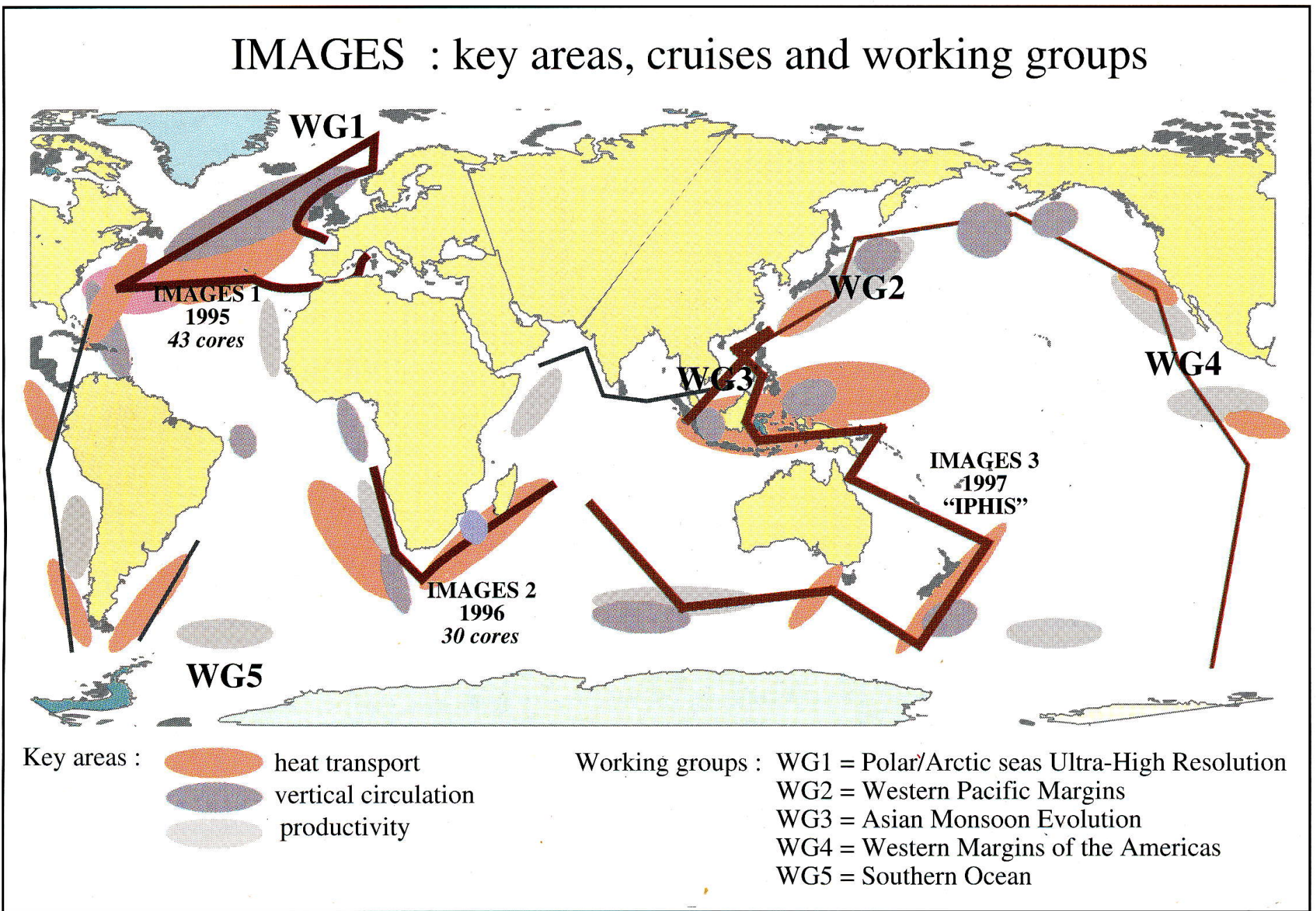


the southeastern Atlantic upwelling region over the last 300000 years.

Participation and co-sponsoring by 7 countries and university consortia: France, Germany, Taiwan, UK, South Africa, Portugal and The Netherlands.

23 giant cores (to $40 \mathrm{~m}$ ) and 19 gravity cores were collected. Sediment accumulating at rates over $15 \mathrm{~cm} / \mathrm{kyr}$ will allow temporal resolution of a few hundred years for the study of the Benguela upwelling system variability.
IMAGES 3 (IPHIS MD 106, May-July 97) Southern Ocean south of Australia and a South-North transect from South-East New Zealand to Southern China Sea

Chief scientists: J.L. Turon, E. Michel

and L. Beaufort

Main objectives: rapid climatic variability and North-South connexions; the variability of the Pacific warm pool. Delays in the preparation of the project did not permit access to Indonesian waters. That part of the cruise was therefore cancelled. Participation and co- sponsoring by 6 countries and University consortia (France, China, Taiwan, Australia, Germany, New Zealand). The cruise was still on-going at the date of the writing this text. But important successes were already achieved: several cores from the Southern Ocean cover the last 400 to 900000 years with 30-40 m of sediment; and a $16 \mathrm{~m}$ length core was sampled in the Gulf of Carpentaria (Northern Queensland, Australia) in $60 \mathrm{~m}$ water depth (on the continental shelf) over a paleo-lake from the last glacial period.

\section{Selected results obtained within the context of the IMAGES program}

Six abstracts have been selected from the AGU, EUG meetings or recent publications to illustrate progress in the description of past climatic variability using records from rapidly accumulating oceanic sediments. Two periods from the last glacial-interglacial cycles have been chosen: the Heinrich events of marine isotopic stage 3 ( 50 to $15 \mathrm{kyr} \mathrm{BP}$ ), and the last interglacial period (130 to $110 \mathrm{kyr} B P$ ).

\section{- Stratification of the photic zone in the North Aflantic during Heinrich Events recorded by planktonic microfossils}

Presented at AGU fall meeting EOS 77, F21, 1996

Quantitative studies of planktonic assemblages have been conducted in Core MD952042 (37 $\left.48^{\prime \prime} \mathrm{N}-10^{\circ} 10^{\prime \prime} \mathrm{W}\right)$ collected during the IMAGES I cruise on the Iberian Margin by $3146 \mathrm{~m}$ of water depth. The core is $37 \mathrm{~m}$ long and spans the last climatic cycle. Heinrich Events are indicated by sharp increases in magnetic susceptibility. Their stratigraphic positions in the core are in good agreement with the oxygen isotope stratigraphy. These levels are marked by synchronous, pronounced increases in the absolute and relative abundances of:

1) Florisphaera profunda (coccolith),

2) a cold morphotype of Coccolithus pelagicus (coccolith)

3) Neogloboquadrina pachyderma (planktonic foraminifera).

Coccolithus pelagicus and N. pachyderma are cold water species which migrated southward with cold waters produced by melting of ice during these events. Florisphaera profunda is a warm to temperate water species, which therefore should not cohabit with the two former species. Florisphaera profunda lives in the deepest part of the photic zone between $80 \mathrm{~m}$ and $150 \mathrm{~m}$. The fact that these three species are found together in the sediment suggests that the cold melt waters were

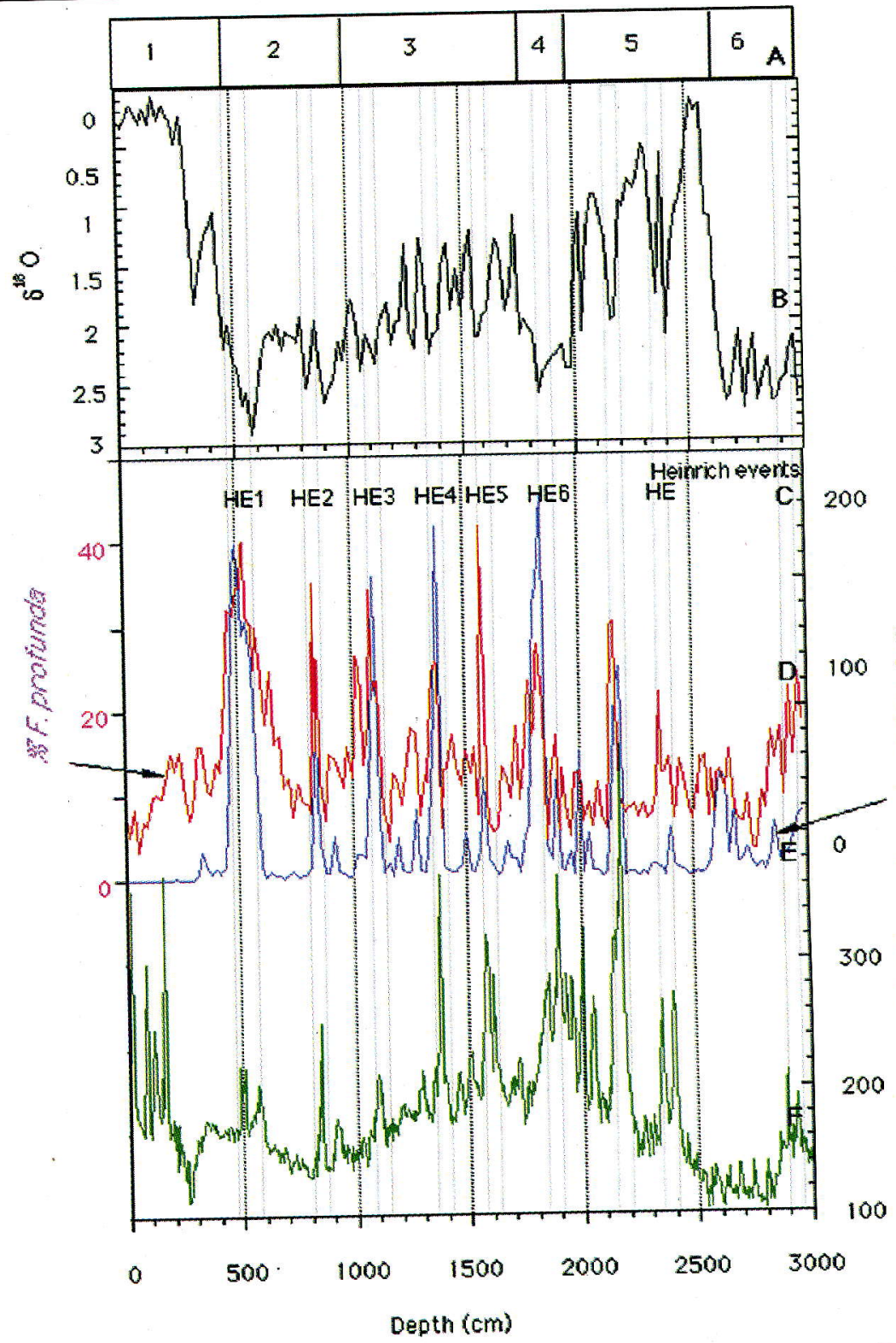

Fig. 2:

Distribution of several paleoclimatic proxies along core MD 952042 (Iberic margin)

A: Marine Isotopic Stages 1 to 6 (covering the last $150 \mathrm{kyr}$ ). B: $\delta^{18} \mathrm{O}$ of G. bulloides, a planktic foraminifera species. C: position of the Heinrich events (as traced by the sediment magnetic susceptibility). D: Relative coccolith distribution of Florisphaera profunda. E: Relative foraminiferal distribution of the polar species $N$. pachyderma s. F: Low field magnetic susceptibility 
distributed only in the upper part of the photic zone and that they were lying above warmer water in the deep photic zone. A strong inverse thermocline was thus present in the photic zone during the Heinrich Events producing a decrease in primary productivity. Our results indicate that thick tongues of melt waters reached a latitude of $37^{\circ} \mathrm{N}$ during Heinrich events in the North Atlantic.

\section{Bouldoire, L. Beaufort, O. Cayre, E. Vincent, Y. LANCELOT \\ LGQ-CNRS, CEREGE \\ 13545 Aix-en-Provence, France e-mail: beaufort@arbois.cerege.fr \\ NJ Shackleton}

Godwin Laboratory, University of Cambridge, ŮK

\section{- Glacial to Recent changes in the flow rates of deep water masses in the North- East Aflantic}

Based on a presentation at EUG Strasbourg Abst. suppl. 1, Terra Nova 9, 611, 1997

Relative flow speeds of major water in the N.E. Atlantic, have been inferred via the "sortable silt" grainsize proxy (McCave et al, 1995). Given the conclusion of Le Grand and Wunsch (1995) that isotopic tracer data at the LGM are consistent with both modern flow rates and a circulation rate of half the modern NADW flux, and that "the central need is for a data type capable of setting the overall rates of water movement", the type of data given here are of unique potential significance.

Records from 12 sites in the Iceland, Rockall and Porcupine basins of the North East Atlantic, back to at least late stage 3 and in some cases stage 6 have been studied. The water masses involved are characterised as Lower Deep Water (LDW, southern source), Lower North Atlantic Deep Water (LNADW, probable Norwegian Sea source), and Intermediate Water (IW, formed by cooling south of the Greenland-Scotland Ridge similar to modern Labrador Sea Water). Water mass designation is based on published $\delta^{13} \mathrm{C}$ and cadmium data. IW on Bjorn Drift south of Iceland shows a striking increase in speed during isotopic stage 2 with lower flow speeds in stage 3 (back to $45 \mathrm{ka}$ ) similar to those from $14 \mathrm{ka}$ to present. On the flanks of Rockall Bank this water flows rapidly until the end of the Younger Dryas, then slows. This is believed to be due to an increased formation rate of IW during the LGM. Winnowed coarse silt bands in stage 2 in Rockall Trough suggests glacial IW formation in Northern Rockall Trough. The most probable candidate for glacial LNADW is found at $2350 \mathrm{~m}$ on northern Gardar Drift in the Iceland basin. This shows high speed in stage $5 \mathrm{e}$, variable speeds with maxima about the same as modern values during later stage
5 , and stages 4 and 3 , and a pronounced decrease between 28 and $18 \mathrm{ka}$ in stage 2 . LDW flow speed is spatially variable. It is at a minimum during the LGM along the Celtic Sea continental margin and in the South Rockall Gap. However in the southern part of the Iceland Basin, and especially in the Charlie Gibbs Fracture Zone, the stage 2 flow was at maximum, declining through most of the Holocene. The slow flow in most places (except CGFZ) during the LGM suggests a generally sluggish deep ocean of LDW overlain by vigourous intermediate water. This supports the second scenario of Le Grand and Wunsch.

\section{Full references from the author:}

I.N. McCave (mocave@esc.cam.Ac.uk)

Department of Earth Sciences,

University of Cambridge, Downing Street,

Cambridge, CB2 3EQ, United Kingdom

\section{- Rapid Climate and Ocean Change in Santa Barbara Basin, California}

Results in part presented in Nature 379: 243-246, 1996

Considerable interest exists about the nature and mechanisms of rapid global climate change and of related biospheric responses. The cores taken at Ocean Drilling Program Site 893 represent the highest resolution sedimentary record of ocean environmental and biotic changes from anywhere in the ocean over the last 160 kyrs and are providing unique opportunities to study rapid climate change.

The Santa Barbara Basin record shows strong evidence for major instability of the marine environment and ecosystem off coastal California during the late Quaternary (Kennett \& Ingram, 1995; Behl \& Kennett, 1996). This instability occurs over a range of time-scales, but is most dramatically shown in association with a sequence of 18 DansgaardOeschger $(\mathrm{D} / \mathrm{O})$ climatic oscillations that occurred during the last 80 kyrs (Behl \& Kennett, 1996). These extremely rapid and major climatic warming episodes (interstadials) were first recognized in the Greenland Ice Sheet where they have been tied to synchronous $\mathrm{CO}_{2}$ and methane fluctuations. The Santa Barbara Basin record demonstrates that sea surface temperatures increased and decreased very rapidly over 50 to 70 years, at both the initiation and termination of the interstadials, as was the case in Greenland. This similarity suggests a remarkably tight coupling between the

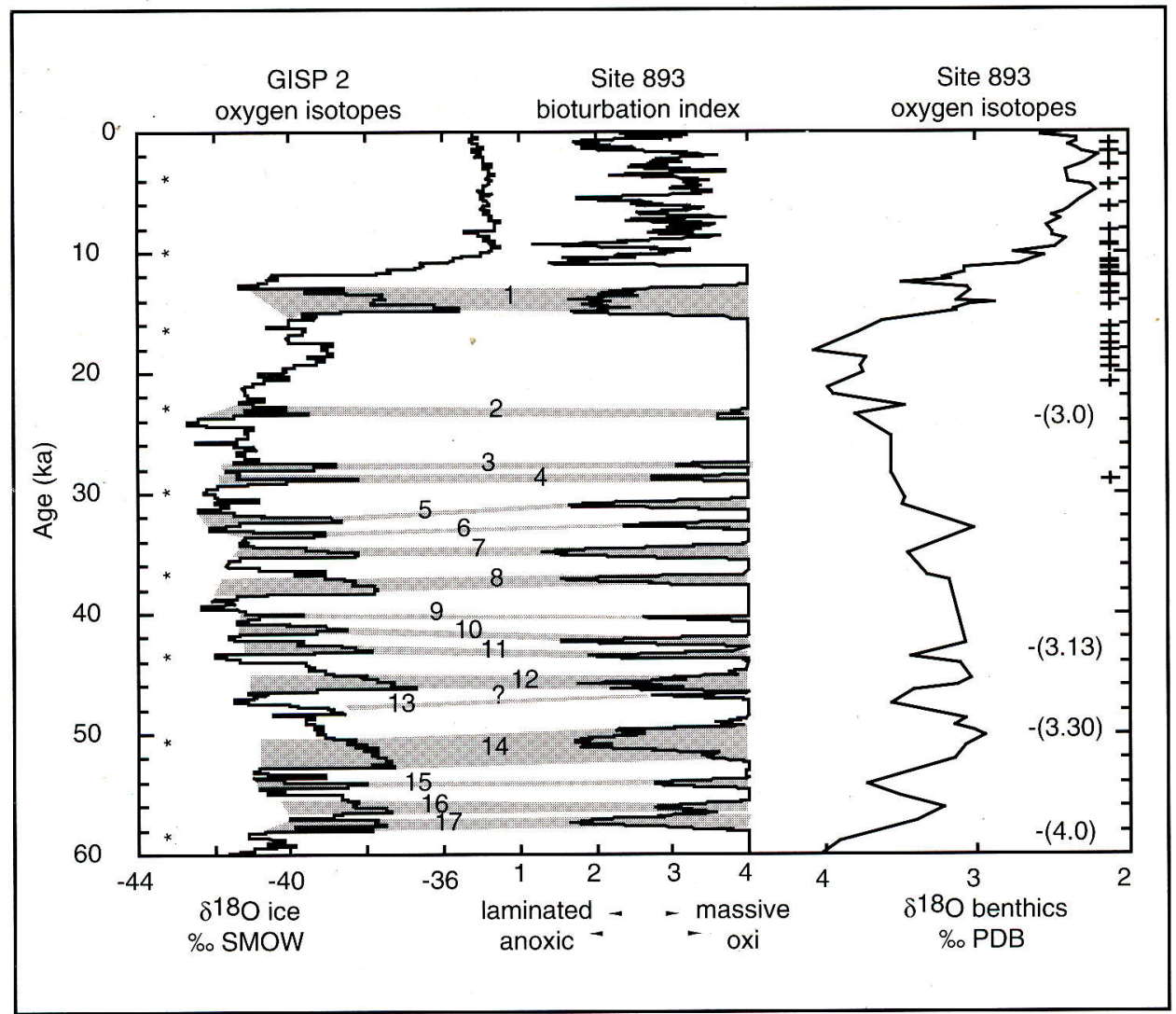

Fig. 3 (adapted from Nature 379, 244, 1996):

Comparison of ODP site 893 (Santa Barbara Basin, California) bioturbation index and benthic foraminiferal $\delta^{18} \mathrm{O}$ records with $\delta^{18} \mathrm{O}$ ice time series from GISP2

Anoxia events (laminations) are reported with the same numbering as the warm interstadials in Greenland. Chronologies for GISP2 and site 893 were independently derived. Radiocarbon age control points $(+)$ and SPECMAP data used for the site 893 age model are shown to the right. The base of each core interval in Hole $893 \mathrm{~A}$ is indicated by arrows to the left. Between 500 and 1250 yr may be missing at the two uppermost core breaks. 
atmosphere, the northern hemisphere cryosphere and hydrosphere. In Santa Barbara, oxygen isotope data indicate that seasurface temperatures initially increased up to $7^{\circ} \mathrm{C}$ in $<70$ years before stabilizing at $\sim 4^{\circ} \mathrm{C}$ warmer than before the $\mathrm{D} / \mathrm{O}$ event. An extraordinary feature of this isotopic record are the $\sim 0.5 \% \circ \delta^{18} \mathrm{O}$ overshoots occurring near the beginning of the interstadials, producing a sawtooth pattern familiar in other records of Quaternary climate change. This feature suggests the involvement of brief, strong greenhouse gas feedback mechanisms, associated with the initiation and termination of the interstadials.

The rapid climate changes are closely linked with changes in oxygenation in the basin as reflected by oscillations between laminated and non-laminated sediments and in benthic foraminiferal assemblages. These fluctuations in the benthic environment of Santa Barbara Basin were controlled by oscillations in the oxygenation of intermediate waters along the California margin. The oscillations between oxic and dysoxic conditions were also extremely rapid. Benthic foraminiferal assemblages associated with laminated sediments are dominated by low oxygen tolerant taxa including Bolivina tumida and Buliminella tenuata. Assemblages associated with non-laminated sediments typical of cooler episodes are dominated by taxa typical of oxygenated waters.

Full references available from the author:

J.P. KeNNETT (KENNET@MSI.UCSB.EDU),

I. Hendy, K. Cannariato

Department of Geological Sciences and Marine

Science Institute,

University of California,

Santa Barbara, USA

R. BEHL

Department of Geological Sciences,

California State University,

Long Beach, USA

\section{- Southern and Northern Hemisphere climatic changes: synchronous or not ?}

adapted from EUG Strasbourg Abst. suppl. 1, Terra Nova 9, 613, 1997 and Paleoceanography in press

High resolution records of planktonic foraminifera abundances and stable isotopes of benthic and planktic foraminifera in late Quaternary sediment cores from the South Atlantic have raised the question whether climate and circulation changes in the Southern Hemisphere are synchronous or offset from those in the North. This question is very important for the discussion of possible forcing and response mechanisms in the course of global climate change as discussed for example by Imbrie et al. $(1992,1993)$ with respect to the Milankovitch forcing. Recent work on climate changes on sub-Milankovitch frequencies suggests that the Southern Hemisphere surface ocean has not varied

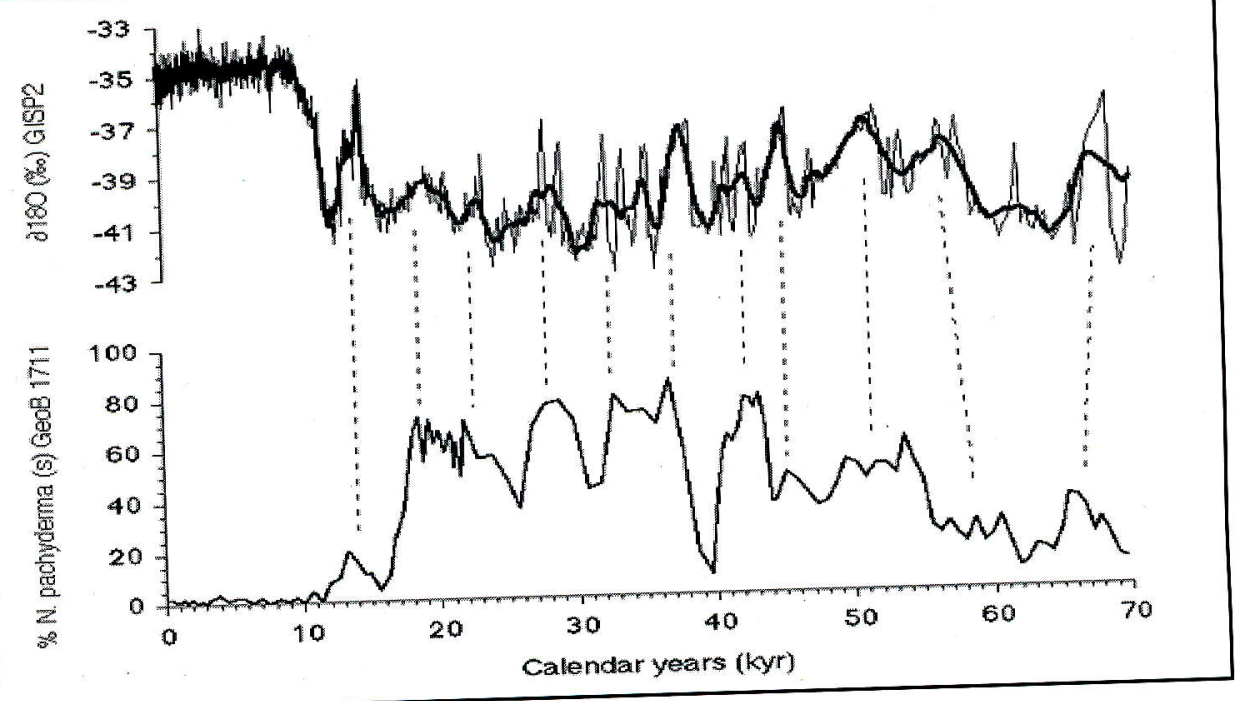

Fig. 4:

Comparison between the oxygen isotope record from Greenland GISP2 ice core and relative abundances of left-coiling Neogloboquadrina pachyderma (\% of total planktonic foraminifera) from Namibian core GeoB 1711-4 (2399' S, 12 22.6' E, 1967 m water depth)

For clarity of correlation the GISP2 oxygen isotope data has been smoothed with a 21 pt running average (thick line) with original data (thin line) superimposed. (Source of foraminiferal and ice core data, as well as ice and sediment core chronologies are reported in Little et al. 1997). Tie lines assign periods of strong trade wind induced upwelling off Namibia, as indicated by the 'PS'-Events (peaks in N. pachyderma (sin) percentages) with warm interstadials as recorded in the Greenland ice cap.

synchronously with respect to Northern Hemisphere climate fluctuations (Charles et al. 1996).

New records of the 'cold-water' planktonic foraminifera Neogloboquadrina pachyderma (sinistral) recovered from the Benguela upwelling system off Namibia reveal events of strong upwelling at subMilankovitch frequencies during the last glacial period between 70 and $10 \mathrm{kyr}$ BP. The timing of these rapid fluctuations in relative abundance of $N$. pachyderma (sin), constrained by radiocarbon datings, implies that strong wind-driven upwelling events in the South Atlantic occured simultaneously with warm periods in the Northern hemisphere, documented in Greenland ice cores. This therefore supports the finding of Charles et al. (1996). The correlation between 'PS'-events (Periods of high abundances of N. pachyderma sinistral) and climate changes known as the Dansgaard-Oeschger cycles, suggests large scale climatic teleconnections between the North Atlantic and South Atlantic surface circulation related to the trade wind systems. Based on the timing of 'PS'-events younger than 50 kyr BP relative to ice core warm interstadials, we assume that during periods of increased southeast trade wind intensity the northward transfer of subtropical surface waters enhanced the cross-equatorial heat transport. The increased supply of warm water to the Northern high latitudes via the Gulf Stream may have favoured the rapid warming of Northern Hemisphere climate on millennial time scales and increased the delivery of moisture to the higher latitudes, accelerating the growth of continental ice sheets. This scenario implies that Northern and Southern Hemisphere asynchronous behaviour at suborbital timescales relies on fluctuations in northward cross-equatorial heat transport into the North Atlantic forced by the subtropical trade wind system.

Full references from the authors:

\section{R. SCHNeider}

Fachbereich Geowissenschaften

Universität Bremen, 28334 Bremen, Germany

M. LITTLE

Geology \& Geophysics

University of Edinburgh, Edinburgh EH9 3JW

Scotland, United Kingdom

\section{- A high resolution record of marine mid- latitude $5 \mathrm{~d} / 5 \mathrm{e} / \mathrm{Termination} \mathrm{Il:}$ surface and deep water properties in the western North Atlantic.}

Derived in part from a presentation at AGU San Francisco, EOS suppl. 77, 46, F15, 1996

As part of IMAGES, a 52.7 meter sediment core was collected from the Bermuda Rise

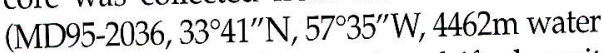
depth), a high sedimentation drift deposit where isotopic stage 5 e occurs at $43 \mathrm{~m}$ depth. We have studied stage $5 \mathrm{e}$ and the adjacent climate boundaries in detail for planktonic and benthic $\delta^{18} \mathrm{O}$, benthic $\mathrm{Cd} / \mathrm{Ca}$, planktonic foraminifera fragmentation, sediment color, and $\mathrm{Th}_{230}$-based accumulation rates. The 
Bermuda Rise $\% \mathrm{CaCO}_{3}$ record and central Greenland $\delta^{18} \mathrm{O}$ correlate in detail for interstadials during marine stages 3-5a. Significant variability is also seen throughout stage 5 , but there are no substantial fluctuations within peak $5 \mathrm{e}$. Just prior to peak $5 \mathrm{e}$, an abrupt 1-2 kyr cessation of NADW supply to this site is observed. Late in $5 \mathrm{e}$ (about $118 \mathrm{kyr} \mathrm{BP}$ ), there is a rapid shift in oceanic conditions in the western North Atlantic which has not been previously documented. Within a $2 \mathrm{~cm}$ interval, $\% \mathrm{CaCO}_{3}$ drops abruptly, and clay flux, $\mathrm{Cd} / \mathrm{Ca}$, $\%$ fragmentation and red color intensity rise abruptly. These data indicate a coincident increase both in the proportion of southern source waters and recirculation-derived clay supply. The rise in $\mathrm{Cd} / \mathrm{Ca}$, carbonate flux, and red color are short-lived, occurring over less than $8 \mathrm{~cm}$ ( 400 yrs). Immediately after this event, benthic $\delta^{18} \mathrm{O}$ begins a steady descent into marine isotope stage $5 \mathrm{~d}$.

Jess Adkins', Ed Boyle', LLoYd Keigwin², Elsa CORTIO ${ }^{3}$

1: MIT, Boston (eaboyle@mit.edu), 2: WHOI,

Whoods Hole 3: CFR, Gif-sur-Yvette, France

Fig. 5:

Details of the proxy records from core MD 952036 (Bermuda Rise) for the last interglacial period, plotted against age (kyr) : planktonic $(A)$ and benthic $(C)$ foraminiferal isotopic records; changes in $\mathrm{CaCO}_{3}$ as recorded in the gray scale; $C d / C$ a ratio in benthic foraminifera $(D)$; proportion of fragments of foraminifera (E), an index for dissolution; balance between red and yellow in the color reflectance spectra $(F)$, a proxy for the mineralogical changes between clay and carbonate content $(G)$
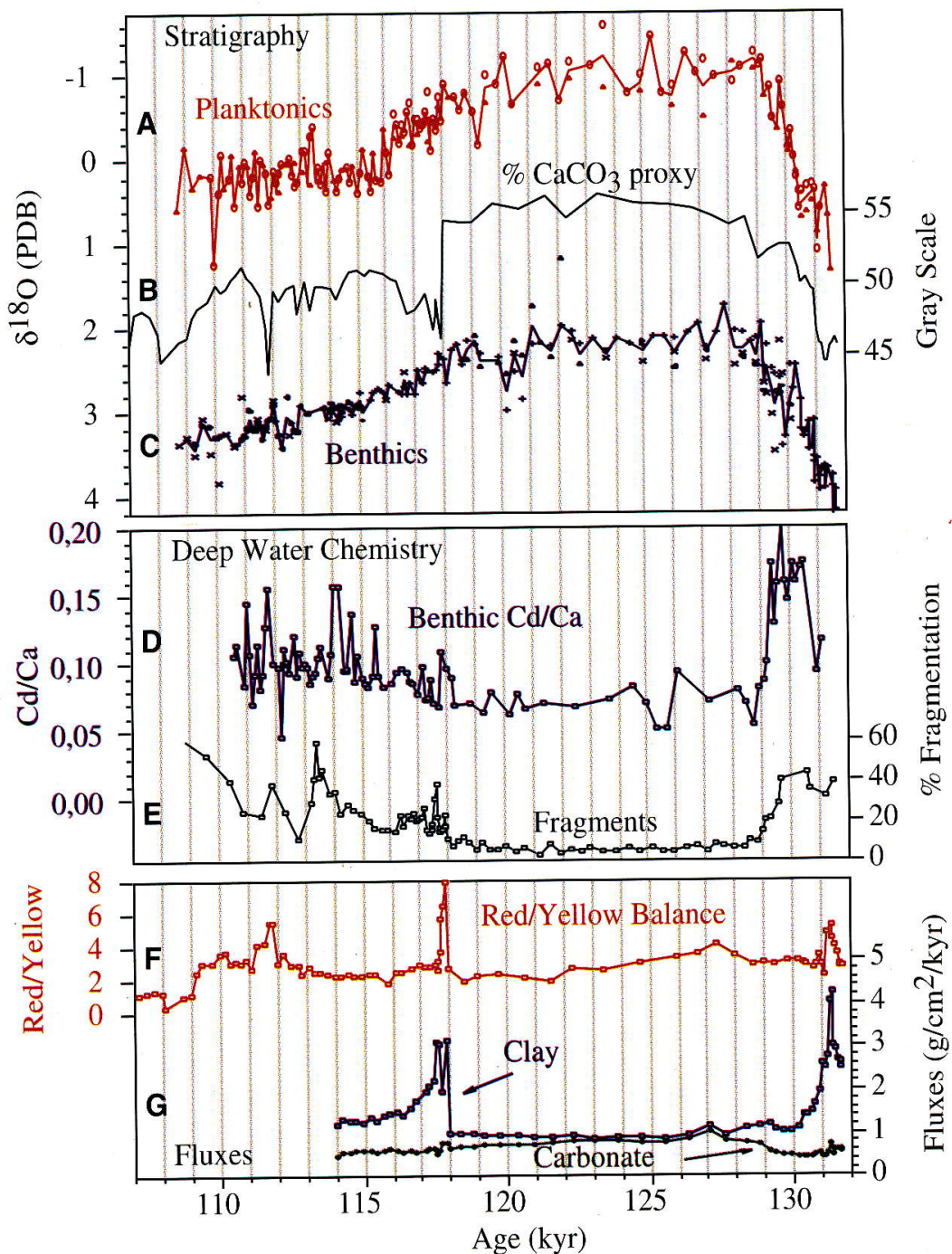

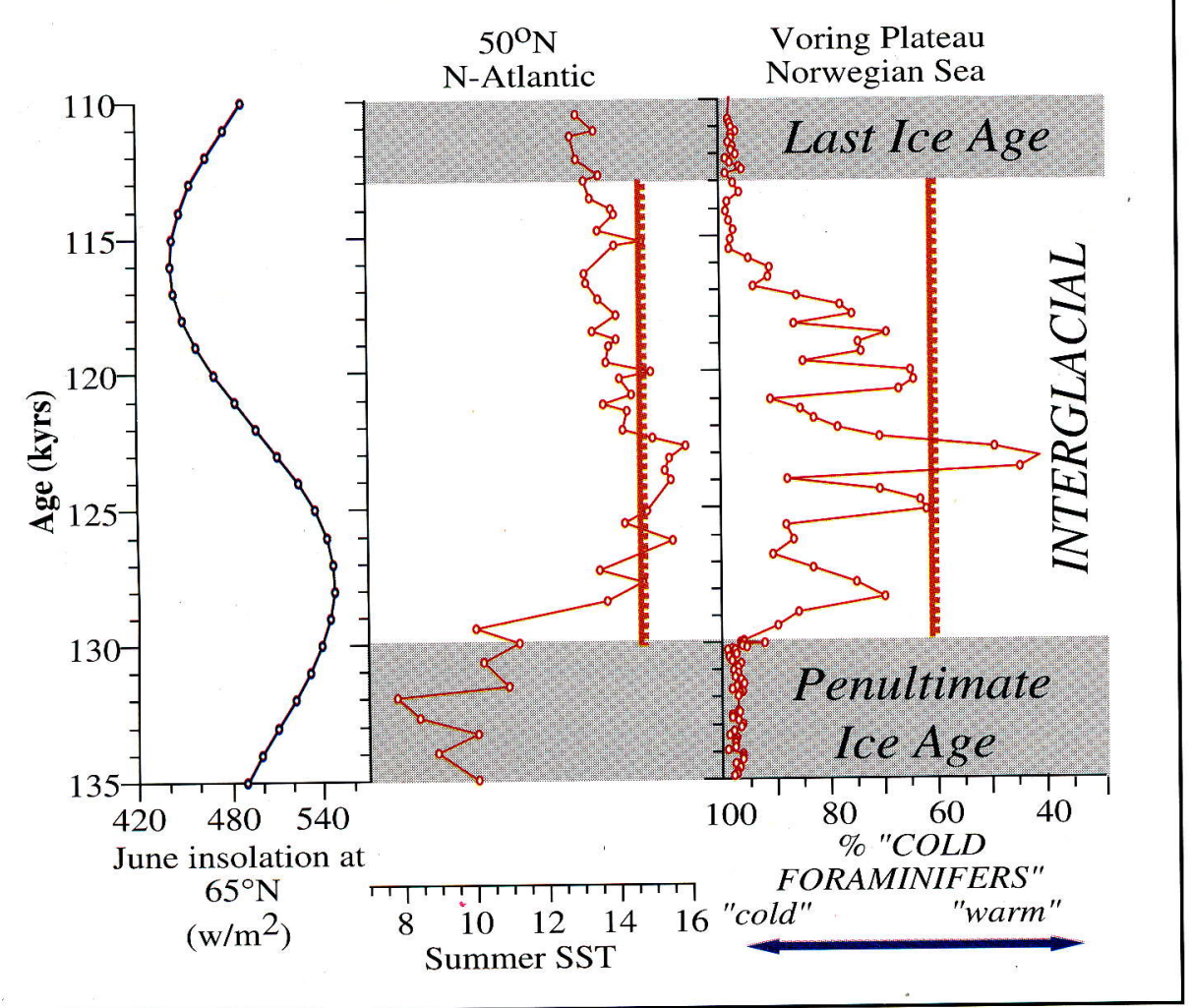

\section{- Climate variability in the last interglacial}

The Nordic Seas is an important area for water mass formation and transformation. Oceanic heat flux (The Nordic Heat Pump) strongly modifies regional climate. Convection and advection provide deep and intermediate water that circulates into the Arctic and Atlantic Oceans. It is also an area of major freshwater fluxes, strong fronts and intensive mixing. This makes the Nordic Seas potentially very sensitive to various forcings, with possible resulting strong influence on the global ocean circulation. Here we document that during the previous interglacial period SST in this region was highly variable with a sequence of high amplitude fluctuations in heat flux and circulation style. This contrasts the more stable situation of the present interglacial.

Fig. 6:

Comparison of insolation curve $\left(65^{\circ} \mathrm{N}\right.$, June, left) and proxy temperature records from core NA87-25 in the Northeast Atlantic at $54^{\circ} \mathrm{N}$ (Cortijo et al, Nature 372, 446-448) and Eastern Norwegian Sea core ODP 644 at $66^{\circ} \mathrm{N}$ (Fronval and Jansen, Nature 383, 806-810) for the last interglacial. 